\title{
TRIGGERS OF MUHAMMADIYAH TEACHERS COMMITMENT TO DEVELOP THE QUALITY OF SCHOOL
}

\author{
Sukirman ${ }^{\text {a* }}$ \\ a*Universitas Ahmad Dahlan \\ Jl. Kapas No.9 Daerah Istimewa Yogyakarta, Indonesia. sukirman@mp.uad.ac.id
}

\begin{abstract}
This study aims to look at various components triggering the commitment of Muhammadiyah teachers in developing the quality of Muhammadiyah schools. This research uses a quantitative method involving 60 elementary school teachers with a varied work period. The analysis used is multiple regression analysis to measure the independent variable on the dependent variable. The results of this study state that the relative advantage, compatibility, trialability, ease of development, ease of work, result demonstrability, image, and voluntariness variables can predict the commitment of teachers in developing the quality of Muhammadiyah elementary schools with an F value of 23,717 and a probability value of 0,000 . Meanwhile, of the eight variables, only the compatibility and voluntariness variables have a significant influence with the probability values of 0.036 and 0,000 .
\end{abstract}

Keywords: Teacher, commitment, quality, school

Received: 12 Oct 2019 - Revised: 2 Nov 2019 -Accepted 14 Dec 2019 -Available online 30 Dec 2019

\section{INTRODUCTION}

Currently the world community is entering the era of the industrial revolution 4.0 which is marked by various things namely, 1) the existence of all-powerful data, 2) the existence of various autonomous robots; 3 ) the existence of a simulation system; 4) system integration; $5)$ the existence of a network between objects; 6) the existence of intelligent physicalcomputing network systems; 7) the existence of an internet-based system; 8) the presence of additive manufacturing; and 9) augmented reality (Saurabh Vaidya et al., 2018). Industry 4.0 is a new concept that was mentioned for the first time in 2011 at the Hannover Fair in Germany (Santos and Jorge 2017). The industrial era 4.0 promises to increase manufacturing flexibility (Zhong et al., 2017), but one thing that must not be forgotten is that there must be an assessment of sustainability in the manufacturing context (Chaim et al., 2018), because manufacturing in the industrial era 4.0 has unique potential for unlocking environmentally friendly manufacturing (de Sousa Jabbour et al., 2018).

Based on these conditions, the existing education of course will naturally also move towards a condition that is different from before. One of the differences in the realm of education today is the emergence of onlinebased education, online-based education is one of the supporters in supporting the quality of education today (Delva et al. 2019). Effective quality education is one of the most efficient tools to empower individuals and help people get out of poverty and exceptions (Kurilovas 2018).

To make quality education, of course, must be supported by policies that provide opportunities for education personnel to bring education into a better realm. Educational policies that restore quality and equality are important, which are not only important for students but also for the overall sustainable 


\section{Sukirman. /Journal of Educational Administration Research and Review / \\ Vol. 3 No. 2 December 2019}

development of society (Zhang, Qin, and Liu 2019).

In an effort to protect education and all elements in it against all possibilities that could have happened, then an education regulation or regulation was made. The design of the roadmap as well as education policies and regulations must have the support of various education stakeholders (Tikly 2011). Meanwhile, in the aspect of learning, there have also been many developments with the emergence of various new learning models or existing learning models that have been modified, such as the addition of regulations in the process of inquiry learning to make inquiry learning more successful (Modrek et al., 2017). This also applies in skills education, specifically for skills education, students are also introduced to the regulations that will be used when they work carrying out their duties, the introduction is done so that students are not surprised by regulations in the workforce and do not commit violations (Libner 2016).

The quality of education can be seen from various perspectives, one of which is by seeing how high the quality of literacy that is owned by students, as it is known that in the $21 \mathrm{st}$ century there are several literacies that must be possessed namely, 1) information literacy; 2) media literacy; 3) ICT literacy (Information and communication technologies) (Trilling \& Fadel, 2009: 7-71). Meanwhile, Aoun (2017) states that the literacy that must be possessed in this modern era is digital literacy, technological literacy, and human literacy (Yahya 2018).

Based on that, of course, a teacher who is a pioneer in an educational process must of course have a commitment to always maintain the quality of education by maintaining the quality of schools as formal institutions in the education process.

\section{Model of Perceived Characteristics of Innovating Theory}

Diffusion is the process when an innovation is communicated through certain channels from time to time among members in the social system and is a special type of communication relating to the dissemination of messages that are new ideas (Rogers 1983). Meanwhile, diffusion offers five attributes that can be used to communicate an innovation into a social system, which includes Relative adventage, Compatibility, Complexity, Observability, Trialability (Rogers 1983) (Compeau et al., 2007). The theory is not only applied in the realm of technology introduction in society but also can be applied in the social field.

The perceived characteristics of innovating theory model identifies eight attributes, namely a) relative advantage; b) compatibility; c) trialability; d) ease of use; e) visibility; f) demonstration result; g) image; and $\mathrm{h}$ ) voluntariness (Moore and Benbasat 1991).

\section{METHODS}

This research uses a quantitative method involving 60 teachers from 15 elementary schools in the Special Region of Yogyakarta, Indonesia. The research data was taken by distributing questionnaires to all respondents. The questionnaire used applies the Likert scale by providing four alternative answers to each question raised namely 1) strongly disagree, 2) disagree, 3) agree, and 4) strongly agree (Likert, 1932).

The analysis used to test the hypotheses proposed in the study uses regression analysis, while the hypotheses proposed in this study are as follows.

$\mathrm{H} 1$ :There is a significant influence of relative adventage to teacher commitment

$\mathrm{H} 2$ : There is a significant influence of compatibility to teacher commitment

H3: There is a significant influence of trialability to teacher commitment

H4: There is a significant influence of ease of development to teacher commitment

H5: There is a significant influence of ease of work to teacher commitment

H6: There is a significant influence of the results that can be shown on teacher 


\section{Sukirman. /Journal of Educational Administration Research and Review /}

Vol. 3 No. 2 December 2019

commitment

H7: There is a significant influence of the image to teacher commitment

H8: There is a significant influence of volunteerism to teacher commitment

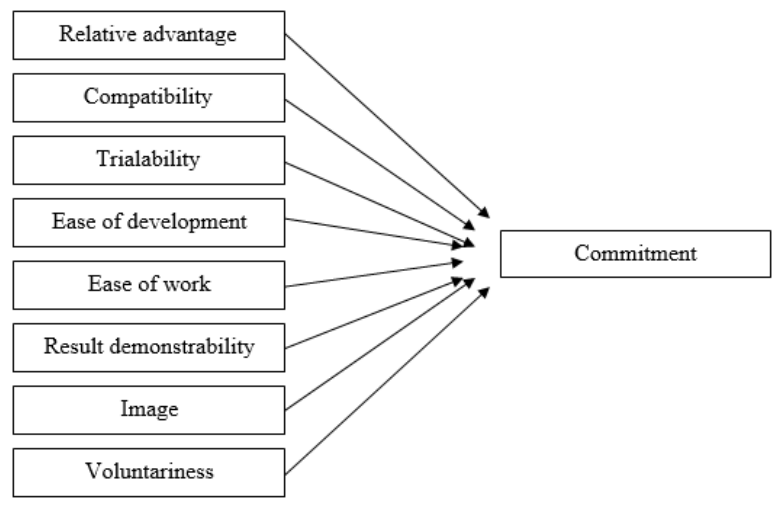

Figure 1. Research hypothesis

\section{RESULTS AND DISCUSSION}

\section{A. Result \\ Demographic Data of Respondents}

Based on demographic data obtained shows that the number of respondents who were male were 9 teachers (15\%) and those who were female were 51 teachers $(85 \%)$. Teachers aged under 40 years were 36 teachers $(60 \%)$ and those over 40 years were 24 teachers (40\%) with the youngest age being 22 years and the oldest was 73 years. The tenure of teachers who are above 10 years is 14 teachers $(23.33 \%)$ and those who have tenure of under 10 years are 36 teachers $(76.67 \%)$. The following respondents data is displayed in tabular form.

Table 1. Demographics of Respondents

\begin{tabular}{ccc}
\hline Variable & Frequency & Percentage(\%) \\
\hline 1. Gender & & \\
Male & 9 & 15 \\
Women & 51 & 85 \\
2. Age & & \\
$\quad<40$ years & 36 & 60 \\
$\quad>40$ years & 24 & 40 \\
3. Years of service & & \\
$\quad<10$ years & 36 & 76,67 \\
$\quad>10$ years & 14 & 23.33 \\
\hline
\end{tabular}

Based on the results presented in table 1. shows various interpretations conveyed including that the value of $\mathrm{R}$ Square of 0.888 which indicates that as much as $88.8 \%$ of variance can be predicted independent variables to be combined with the dependent variable. meanwhile an $\mathrm{F}$ value of 23.717 with a significance of 0.000 indicates that the model used in this study is significant, meaning that the relative advantage, compatibility, trialability, ease of development, ease of work, result of demonstrability, image, and voluntariness variables can be used to predict commitment teacher in developing the quality of schools especially Muhammadiyah elementary schools.

For a detailed explanation shows that the relative advantage variable has a value $\beta=$ 0.127 with a probability value of 0.104 which indicates that the variable does not significantly influence the dependent variable, namely the teacher's commitment in developing the quality of Muhammadiyah schools. The compatibility variable has a value $\beta=0.186$ with a probability value of 0.036 which indicates that the variable has a significant effect on the dependent variable, namely the commitment of teachers in developing the quality of Muhammadiyah schools. Trialability variable has a value $\beta=0.135$ with a probability value of 0.213 which indicates that the variable does not significantly influence the dependent variable, namely the commitment of teachers in developing the quality of Muhammadiyah schools.

Meanwhile, the ease of development variable has a value $\beta=0.145$ with a probability value of 0.152 which indicates that the variable does not significantly influence the dependent variable, namely the teacher's commitment in developing the quality of Muhammadiyah schools. The ease of work variable has a value $\beta=-0.044$ with a probability value of 0.682 which indicates that the variable does not significantly influence the dependent variable, namely the teacher's commitment in developing the quality of Muhammadiyah schools. The result demonstrability variable has a value $\beta=0.024$ with a probability value 


\section{Sukirman. /Journal of Educational Administration Research and Review / \\ Vol. 3 No. 2 December 2019}

of 0.837 which indicates that the variable does not significantly influence the dependent variable, namely the teacher's commitment in developing the quality of Muhammadiyah schools.

The last two independent variables show that the image variable has a value $\beta=-0.083$ with a probability value of 0.394 which indicates that the variable does not significantly influence the dependent variable, namely the commitment of teachers in developing the quality of Muhammadiyah schools. Meanwhile, the voluntariness variable has a value of $\beta=0.885$ with a probability value of 0,000 which indicates that the variable has a significant effect on the dependent variable, namely the commitment of teachers in developing the quality of Muhammadiyah schools.

Table 2. Results of Regression Analysis

\begin{tabular}{cccccc}
\hline Model & \multicolumn{2}{c}{ Standardized } & R & F & Sig \\
& \multicolumn{2}{c}{ coefficients } & Squar & & \\
Beta & Sig & e & & \\
\hline Constant) & & & 0,888 & 23,71 & 0,00 \\
Relative & - & 0,10 & & 7 & 0 \\
adventage & 0,12 & 4 & & & \\
& 7 & & & & \\
Compatibility & 0,18 & 0,03 & & & \\
& 6 & 6 & & & \\
Trialability & - & 0,21 & & & \\
5,13 & 3 & & & \\
Ease of & 5 & & & & \\
development & 5 & 2 & & & \\
Ease of work & - & 0,68 & & & \\
5,04 & 2 & & \\
Result & 4 & & & \\
demonstrabilit & 4 & 7 & & \\
Image & - & 0,39 & & \\
& 0,08 & 4 & & \\
Voluntariness & 0,88 & 0,00 & & \\
& 5 & 0 & & \\
\hline
\end{tabular}

\section{B. Discussion}

Based on the research results obtained there are some important things to be discussed as a basis for forming recommendations in the end. The eight variables or attributes used in this study include the variables of relative advantage, compatibility, trialability, ease of development, ease of work, result demonstrability, image, and voluntariness. The eight variables used in the model together can be used to predict the commitment of teachers in developing school quality, especially Muhammadiyah elementary schools.

However, partially, the relative advantage, trialability, ease of development, ease of work, result demonstrability, and image variables did not significantly influence teacher commitment in developing school quality, especially Muhammadiyah elementary schools. Meanwhile, compatibility and voluntariness variables significantly influence teacher commitment in developing school quality, especially Muhammadiyah elementary schools.

Referring to these results shows that the teachers involved in this study are in conformity with the Muhammadiyah school, meaning that everything that the Muhammadiyah organization gives to the teacher is already considered in accordance with the teacher's expectations, in addition that everything that the Muhammadiyah organization gives to the teacher has been assessed according to the rules organization that has been established so that there is no need to doubt. This conformity shows the emotional bond between Muhammadiyah teachers involved in research with the Muhammadiyah organization.

In addition to compatibility variables, one more variable that also has a significant effect is voluntariness. The voluntariness variable has an effect of 0.885 on the commitment of teachers in developing the quality of the Muhammadiyah elementary school with a perfect significance value of 0,000 . This clearly shows that the volunteerism of Muhammadiyah teachers involved in this research had a high voluntary involvement in carrying out their duties as teachers in Muhammadiyah elementary schools and that 


\section{Sukirman. /Journal of Educational Administration Research and Review / \\ Vol. 3 No. 2 December 2019}

volunteering became a very strong basis for teachers in developing the quality of Muhammadiyah elementary schools.

This condition is a big advantage for Muhammadiyah organizations that have teachers who have high volunteerism and who are also of high conformity. With these conditions it will facilitate the Muhammadiyah organization to provide a trigger to develop the potential of its teachers, especially Muhammadiyah elementary school teachers. The compatibility and volunteerism of Muhammadiyah elementary school teachers in developing the quality of Muhammadiyah elementary schools shows a positive emotional relationship between these teachers and the Muhammadiyah organization. This condition also shows the success of the Muhammadiyah organization so far in establishing cooperation with its teachers, especially Muhammadiyah elementary school teachers.

\section{CONCLUSION/RECOMENDATION}

Based on the results of research and discussion that has been presented, in this conclusion it can be clearly stated that the variable relative advantage, compatibility, trialability, ease of development, ease of work, result demonstrability, image, and voluntariness together can predict teacher commitment in developing school quality the basis of Muhammadiyah with an F value of 23,717 and a probability value of 0,000 . Meanwhile, of the eight variables, only the compatibility and voluntariness variables have a significant influence with the probability values of 0.036 and 0,000 .

Based on the conclusions that have been submitted, the recommendations that can be submitted in this study are that the Muhammadiyah organization already has a large capital to foster its teachers in developing the quality of Muhammadiyah elementary schools. For this reason, it is appropriate for the Muhammadiyah organization to maintain what has been done so far for its Muhammadiyah elementary school teachers because it has been proven to be in accordance with these teachers and has been proven to make the teachers they have voluntary in developing the quality of Muhammadiyah elementary schools.

\section{REFERENCES}

Chaim, Omar, Bernd Muschard, Edson Cazarini, and Henrique Rozenfeld. 2018. "Insertion of Sustainability Performance Indicators in an Industry 4.0 Virtual Learning Environment." Procedia Manufacturing 21(2017): 446-53. http://www.sciencedirect.com/science/article/pii/ S2351978918301823.

Compeau, Deborah R, Richard Ivey, Darren B Meister, and Christopher A Higgins. 2007. "From Prediction to Explanation: Reconceptualizing and Extending the Perceived Characteristics of Innovating." Journal of the Association for Information Systems 8(1): 409-39.

Delva, Sabianca et al. 2019. "Views of Regulatory Authorities on Standards to Assure Quality in Online Nursing Education." 0: 1-13.

Kurilovas, Eugenijus. 2018. "On Data-Driven DecisionMaking for Quality Education.” Computers in Human Behavior (January): 1-9. https://doi.org/10.1016/j.chb.2018.11.003.

Libner, Joan. 2016. "Priorities for Continuing Education Regarding Regulation: Perceptions of RN-toBSN Students and State Regulators." Journal of Nursing Regulation 7(1): 53-58. http://dx.doi.org/10.1016/S21558256(16)31042-0.

Modrek, Anahid S., Deanna Kuhn, Anne Conway, and Toi Sin Arvidsson. 2017. "Cognitive Regulation, Not Behavior Regulation, Predicts Learning." Learning and Instruction (October 2016): 0-1. http://dx.doi.org/10.1016/j.learninstruc.2017.12. 001 .

Moore, Gary C., and Izak Benbasat. 1991. "Development of an Instrument to Measure the Perceptions of Adopting an Information Technology Innovation." Information Systems Research 2(3): 192-222.

Rogers, Everett M. 1983. Macmillian Publishing Co. Diffusion of Innovations. http://hollis.harvard.edu/?itemid=|library/m/alep h|006256656.

Santos, Maribel Yasmina, and Jorge. 2017. “A Big Data System Supporting Bosch Braga Industry 4.0 Strategy." International Journal of Information Management 37(6): 750-60. http://dx.doi.org/10.1016/j.ijinfomgt.2017.07.01 2.

Saurabh Vaidya, Prashant Ambad, Santosh Bhosle. 2018. "Industry 4 . 0 - A Glimpse." Procedia Manufacturing 20: 233-38. https://doi.org/10.1016/j.promfg.2018.02.034.

de Sousa Jabbour, Ana Beatriz Lopes, Charbel Jose Chiappetta Jabbour, Cyril Foropon, and Moacir 


\section{Sukirman. /Journal of Educational Administration Research and Review / \\ Vol. 3 No. 2 December 2019}

Godinho Filho. 2018. "When Titans Meet - Can Industry 4.0 Revolutionise the EnvironmentallySustainable Manufacturing Wave? The Role of Critical Success Factors." Technological Forecasting and Social Change (October 2017): $0-1$. http://dx.doi.org/10.1016/j.techfore.2018.01.017.

Tikly, Leon. 2011. "A Roadblock to Social Justice? An Analysis and Critique of the South African Education Roadmap." International Journal of Educational Development 31(1): 86-94.

Trilling, Bernie, and Charles Fadel. 2009. "21st Century Skills." Jossey-Bass: 256. http://www.eric.ed.gov/ERICWebPortal/recordD etail?accno=ED528762.
Yahya, Muhammad. 2018. "Era Industri 4.0: Tantangan Dan Peluang Perkembangan Pendidikan Kejuruan Indonesia."

Zhang, Yu, Fei Qin, and Juanjuan Liu. 2019. "Improving Education Equality and Quality: Evidence from a Natural Experiment in China." International Journal of Educational Development 70(November 2018 ): 102078. https://doi.org/10.1016/j.ijedudev.2019.102078.

Zhong, Ray Y., Xun Xu, Eberhard Klotz, and Stephen T. Newman. 2017. "Intelligent Manufacturing in the Context of Industry 4.0: A Review.” Engineering 3(5): 616-30. http://dx.doi.org/10.1016/J.ENG.2017.05.015. 